\title{
Isolation of Clostridium sordellii from abomasum lesions of lambs in Turkey
}

\author{
Mehmet AKAN ${ }^{1}$, Barış SAREYYÜPOĞLU ${ }^{1}$, Taner ÖNCEL ${ }^{2}$, Osman Yaşar TEL $^{1}$, \\ Ziya ILLHAN ${ }^{3}$, Zafer CANTEKİN ${ }^{1}$
}

\begin{abstract}
${ }^{1}$ Department of Microbiology, Faculty of Veterinary Medicine, Ankara University, 06110, Dışkapı, Ankara, Turkey. ${ }^{2}$ Pfizer Inc., Animal Health, Ortaköy, Istanbul, Turkey. ${ }^{3}$ Department of Microbiology, Faculty of Veterinary Medicine, Yüzüncüyıl University, Van, Turkey.
\end{abstract}

\begin{abstract}
Summary: In this study, the isolation of $C$. sordellii from abomasum lesions of lambs and the confirmation of the isolates by polymerase chain reaction (PCR) was attempted. A total of 298 abomasal specimens (swabs) obtained from lambs of 4 to 8 months of age were investigated. Sampled swabs were inoculated onto blood agar plates and incubated anaerobically. Following the incubation grown colonies were identified according to their morphological and biochemical characteristics. C. sordellii was isolated from 17 of 298 specimens (5.7\%). These bacteria were also confirmed to harbour C. sordellii DNA by PCR. In conclusion, the presence of $C$. sordellii in abomasum lesions was demonstrated in Turkey for the first time with this study.
\end{abstract}

Key words: Abomasum lesions, Clostridium sordellii, isolation, lamb, PCR

\section{Türkiye'deki kuzularda abomazum lezyonlarından Clostridium sordellii izolasyonu}

Özet: Bu çalışmada kuzuların abomazum lezyonlarından Clostridium sordellii izolasyonu ve izolatların polimeraz zincir reaksiyonu ile doğrulanması amaçlandı. Çalışma kapsamında 4-8 aylık yaştaki koyunlardan toplanan 298 abomazumdan alınan svab örnekleri incelendi. Sıvabların kanlı agarlara ekimi gerçekleştirilerek anaerobik ortamda inkube edildi. İnkubasyonu takiben şekillenen koloniler morfolojik ve biyokimyasal özelliklerine göre identifiye edildi. İncelen 298 materyalin 17 (\% 5.7)'sinde $C$. sordellii izole edildi. İzolatlar PCR ile C. sordellii DNA'sı yönünden doğrulandı. Sonuç olarak, bu çalışma ile abomazum lezyonlarından C. sordellii izolasyonu Türkiye'de ilk kez gerçekleştirildi.

Anahtar sözcükler: Abomazum lezyonları, Clostridium sordellii, izolasyon, kuzu, PCR.

\section{Introduction}

Clostridia can be isolated from various specimens in different clinical cases, particularly the enterotoxaemia cases. Some species of Clostridia are also found in the normal flora of the gastrointestinal tract. Clostridium sordellii is classified amongst the cytotoxic Clostridium species, and has been isolated from cases of sudden death. Although Clostridium chauvoei and Clostridium septicum are among the agents frequently causing malignant oedema, $C$. sordellii also causes this symptom either alone or in conjunction with other Clostridium species (9). Morris et al. (9), demonstrated the presence of C. septicum and C. sordellii both by culture and a fluorescent antibody test from the specimens obtained from a one-year-old Friesian ewe died because of malignant oedema. This bacterium has also been isolated from abomasitis cases elsewhere in the world $(1,2,7$, 10). Richards and Hunt (10), isolated pure colonies of $C$. sordellii from the liver of a one-month-old lamb which died suddenly. C. sordellii isolations were also reported from a sheep with enteritis (2), from cattle (1), and from foals (5). Lewis and Naylor (7) obtained pure isolates of
C. sordellii in sudden death cases of lambs and reported that this bacterium was more likely to be responsible from these sudden deaths than that had been suggested in the previous reports. Lewis and Naylor (8), isolated $C$. sordellii from 37 sheep of all ages in 29 different flocks, and reported that $C$. sordellii should be considered as an important pathogen of sheep of any age, causing sudden death.

The objective of this study was to attempt the isolation of $C$. sordellii from abomasum lesions of lambs and the confirmation of the isolates by polymerase chain reaction (PCR).

\section{Materials}

In the study, a total of 298 abomasum specimens obtained from lambs of 4 to 8 months of age were investigated. Specimens were obtained from two abattoirs in the cities of Ankara (capital of Turkey in the Middle Anatolia region) and Van (East of Turkey). Abomasum samples (swabs) were obtained from the sites of the organ that had lesions ranging from intense congestion of 
the whole of the mucosa to discrete longitudinal ulcers. Swab samples were placed into the anaerobic jars with gaspacks (Merck) and were transferred to laboratory in material transport case with ice boxes. Specimens were collected between May 2004 and June 2005.

\section{Isolation and identification of $\boldsymbol{C}$. sordellii}

Smears prepared from specimens brought to the laboratory were Gram-stained. Swabs were inoculated onto Stiff agar (containing 5\% sheep blood) plates and incubated at $37^{\circ} \mathrm{C}$ for 48 hours with the aid of anaerobic jars and gaspacks. Following incubation, colonies were examined macroscopically and microscopically and identified according to their biochemical characteristics such as Gram staining, glucose, maltose, mannose, arabinose and lactose fermentation, lecitinase, geletinase, urease, lipase activity, indole production, and esculin hydrolysis (8).

\section{C. sordellii confirmation with PCR}

For the confirmation of strains identified as $C$. sordellii, PCR technique was used for the detection of related DNA in the specimens. DNA extraction and PCR assay were performed according to the method reported by Kikuchi et al. (6). Briefly, DNA was extracted from bacterial cells by a freeze/thaw method (4). DNA extracted from C. sordellii strain provided from Dr. Kikuchi (The University of Tokyo) was used as positive control in the study. DNA extracted from Escherichia coli isolate provided from our laboratory collection constituted the negative control in PCR tests. Forward (ClSOR-F) 5'-TCG AGC GAC CTT CGG-3' and reverse (ClSOR-R) 3'-CAC CAC CTG TCA CCA T-5' primers were used in $C$. sordellii PCR. The PCR mixture contained $10 \mathrm{mM}$ Tris- $\mathrm{HCl}$ and $50 \mathrm{mM} \mathrm{KCl}, 2 \mathrm{mM} \mathrm{MgCl}_{2}$, $200 \mu \mathrm{M}$ dNTP mix (Fermentas, Lithuania), $2 \mathrm{U}$ of Taq polymerase (Fermentas, Lithuania), 20 pmol of each primers and $2 \mu \mathrm{l}$ template DNA made up to $100 \mu \mathrm{l}$ with distilled water. The PCR protocol consisted of one cycle for $2 \mathrm{~min}$ at $94^{\circ} \mathrm{C}$, followed by 35 cycles of $30 \mathrm{sec}$ at $94^{\circ} \mathrm{C}, 30 \mathrm{sec}$ at $55^{\circ} \mathrm{C}$, and $2 \mathrm{~min}$ at $72^{\circ} \mathrm{C}$, and one cycle for $2 \mathrm{~min}$ at $72^{\circ} \mathrm{C}$. The PCR products were analysed by gel electrophoresis in $1.5 \%$ agarose gel and stained with ethidium bromide $(1 \mu \mathrm{g} / \mathrm{ml})$. DNA bands were recorded and evaluated on bio imaging system (Gene Genius, Syngene).

\section{Results}

\section{Isolation and identification of $\boldsymbol{C}$. sordellii}

C. sordellii was isolated from a total of 17 specimens $(5.7 \%)$. Isolation rates of the agent were $4.92 \%$ and $6.96 \%$ for the samples obtained from Ankara and Van, respectively (Table). During the direct microscopic examinations of the specimens after Gram staining, Gram positive, pleomorphic sporulated or nonsporulated bacilli were observed. In the macroscopic examination of culture media after 48 hours of incubation, gray-white colored, convex, rough colonies of 3-4 $\mathrm{mm}$ in diameter, creating a narrow haemolysis were isolated (Figure 1). Following the Gram staining of these colonies, Gram positive, cylinder-shaped bacilli with central spores were observed. Also quite a number of free spores were encountered. After the biochemical examinations, strains showing positive lecitinase, geletinase, glucose, maltose, urease and indole activities, and negative lipase, esculin, mannose, arabinose and lactose activities were identified as $C$. sordellii.

Table. C. sordellii isolation results.

Tablo. C. sordellii izolasyon sonuçları.

\begin{tabular}{lcc}
\hline Abattoir & Sample no & Isolation (\%) \\
\hline Ankara & 183 & $9(4.92)$ \\
Van & 115 & $8(6.96)$ \\
Total & 298 & $17(5.7)$ \\
\hline
\end{tabular}

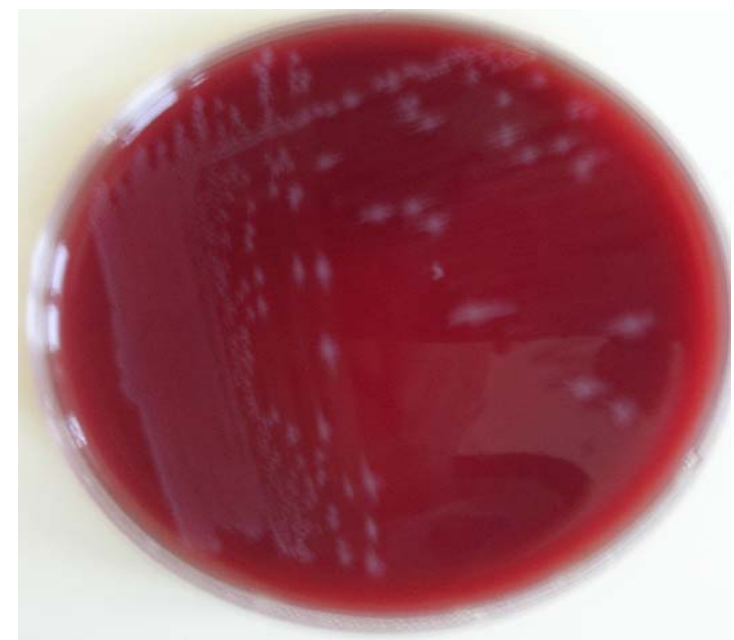

Figure 1. Macroscopic morphology of Clostridium sordellii on stiff agar plate.

Şekil 1. Stiff agarda Clostridium sordellii kolonileri.

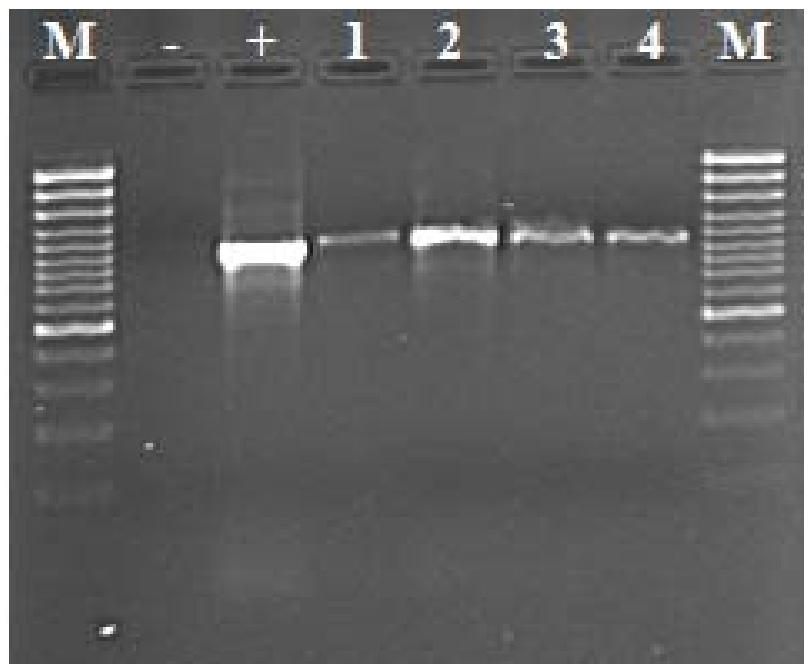

Figure 2. Agarose gel electrophoresis of $C$. sordellii PCR samples. Şekil 2. C. sordellii PCR ürünlerinin agaroz jel elektroforezi. M. 100bp DNA ladder. -. Negative control. +. Positive control (band of 944 bp length). 1-4. PCR results (C. sordellii specific bands of $944 \mathrm{bp}$ ) of DNA extracted from $C$. sordellii isolates. 


\section{C. sordellii PCR}

C. sordellii specific bands of 944 bp were observed following the electrophoresis of PCR amplicons prepared from the extracted DNAs of 17 strains identified as $C$. sordellii according to their morphological and biochemical examinations (Figure 2).

\section{Discussion and Conclusion}

There have been few studies on isolation of $C$. sordellii from clinical cases. In these, $C$. sordellii has been isolated from the cases of sheep from different age groups with malignant oedema and sudden death $(2,7,8$, 10). Morris et al. (9), isolated $C$. sordellii and $C$. septicum from a case of sudden death from one-year-old Fresian sheep. Al-Mashat and Taylor (2), reported $C$. sordellii isolation from adult sheep with enteritis. Most of the restricted studies on $C$. sordelli isolation focused on the cases of sudden death of sheep. C. sordelli was isolated from lambs of 1-month-old (10), and young lambs from cases of sudden death $(7,8)$. In their study, where Lewis and Naylor (8) have investigated the sudden death of young lambs (3-10 week-old), lambs (4-6 months-old) and sheep, they detected lesions in abomasum although differing with the age of study group. After the researchers evaluated their study results, they concluded that $C$. sordellii could cause sudden deaths in all age groups.

C. sordellii isolation was performed for the first time in Turkey with the present study. A rate of $5.7 \%$ of C. sordellii isolation from abomasum lesions in abattoirs indicates that this agent could cause potential health problems and finally losses in sheep. It was also shown that $C$. sordellii widely existed in the region, because the isolation rates of materials obtained from the both abattoirs were similar, and since the materials were obtained from different flocks in the regions. These results also showed that further studies should be focused on related to sudden death syndrome of sheep for the determination of clinical importance of the agent.

It has not been possible to compare the findings of our study with the results of others. While the agent isolation has mainly focused on isolations from sheep exacerbating sudden deaths in previous studies, in this study $C$. sordellii has only been isolated from the material obtained from sheep with abomasum lesions. This study is the first study by this means.

C. sordellii isolation is the appropriate and commonly used method for the diagnosis of infection (8). Molecular techniques are being benefited for the diagnosis of infectious diseases in recent years. Although PCR-based molecular techniques are used for the determination of toxin characteristics of C. sordellii (3,
11), there is only one study about the direct detection of the agent. In the study, PCR method was standardized for the detection of the agent (6). In this study, PCR technique was used for the confirmation of isolated $C$. sordellii strains and $C$. sordellii specific bands were detected in the electrophoresis of all DNA samples extracted from the strains identified as C. sordellii following morphological and biochemical investigations. These results indicated that PCR can be used for the confirmation of $C$. sordellii isolates obtained from different materials and/or for the molecular diagnosis of infection in $C$. sordellii suspected cases after the standardization of the PCR test.

In conclusion, with this study, the presence of $C$. sordellii in ovine abomasal samples was demonstrated, and this was confirmed by PCR. The findings of similar existence rates of $C$. sordellii in different sheep flocks showed us the need for further studies about $C$. sordellii infections in sheep flocks and also the need of preparing precautions against $C$. sordellii.

\section{Acknowledgements}

The authors gratefully acknowledge the contributions and help of Dr. Kikuji Itoh and kind supports of Pfizer Inc.

\section{References}

1. Al-Mashat RR, Taylor DJ (1983a): Bacteria in enteric lesions of cattle. Vet Rec, 112, 5-10.

2. Al-Mashat RR, Taylor DJ (1983b): Clostridium sordellii in enteritis in an adult sheep. Vet Rec, 112, 19.

3. Green GA, Schue V, Monteil H (1995): Cloning and characterization of the cytotoxin L-encoding gene of Clostridium sordellii: homology with Clostridium difficile cytotoxin B. Gene, 161, 57-61.

4. Grossman N, Ron EZ (1975): Membrane-bound DNA from Escherichia coli: extraction by freeze-thaw-lysozyme. FEBS Lett, 54, 327-329.

5. Hibbs CM, Johnson DR, Reynolds K, Harrington RJR (1977): Clostridium sordellii isolated from foals. Vet Med Small Anim Clin, 72, 256-258.

6. Kikuchi E, Miyamoto Y, Narushima S, Itoh K (2002): Design of species-specific primers to identify 13 species of Clostridium harbored in human intestinal tracts. Microbiol Immunol, 46, 353-358.

7. Lewis CJ, Naylor R (1996): Sudden death in lambs associated with Clostridium sordellii infection. Vet Rec, 138, 262.

8. Lewis CJ, Naylor R (1998): Sudden death in sheep associated with Clostridium sordellii. Vet Rec, 142, 417421.

9. Morris WE, Uzal FA, Fattorini FR, Terzolo H (2002): Malignant oedema associated with blood-sampling in sheep. Australian Vet J, 80, 280-281. 
10. Richards SM, Hunt BW (1982): Clostridium sordellii in lambs. Vet Rec, 111, 22.

11. Uzal FA, Hugenholtz P, Blackall LL, Petray S, Moss S, Assis RA, Miyakawa MF, Carloni G (2003): $P C R$ detection of Clostridium chauvoei in pure cultures and formalin-fixed, paraffin-embedded tissues. Vet Microbiol, 91, 239-248.
Geliş tarihi: 22.11.2006 / Kabul tarihi: 10.10.2007

\section{Address for correspondence}

Prof. Dr. Mehmet Akan

Ankara University, Faculty of Veterinary Medicine

Department of Microbiology,

06110 Dişkapı, Ankara, Turkey.

e-mail:akan@veterinary.ankara.edu.tr 